\title{
Building peace through mystic philosophy: study on the role of Sunan Kalijaga in Java
}

\author{
Waston \\ Universitas Muhammadiyah Surakarta \\ E-mail:was277@ums.ac.id \\ DOI: 10.18326/ijims.v8i2. 281-308
}

\begin{abstract}
This paper aims to study the teachings of peace invented in the Javanese tradition particularly by Sunan Kalijaga. Sunan Kalijaga was a Muslim saint in the $15^{\text {th }}$ century $\mathrm{AD}$ who taught mystical-philosophical teachings. His role permeates in the Javanese tradition so peaceful values that are embedded in its teachings still be traced and developed. We conducted a literature study on the role, influence and legacy of Sunan Kalijaga. We focused on his philosophical approach to religious thought as oppose to the mystical aspect. Our findings show that Sunan Kalijaga succeeded in using proper choice of words to combine Islamic values and predominant cultural elements (e.g., Hinduism, Buddhism). Therefore, instead of using the Arabic terms, Sunan Kalijaga used many old Javanese and Sanskrit terms commonly used in the $15^{\text {th }}-16^{\text {th }}$ century Javanese society. As an implication, Sunan Kalijaga created terms that are less Islamic but loaded with Islamic values. His examination is not only inherited into terms, but also practices, symbols and institutions. Among those Javanese traditions, some of them are critically important in supporting peace-building. This paper reaps the peaceful values of the Sunan teachings in the hope of countering the stream of extreme ideologies that have recently flooded the public.
\end{abstract}


Paper ini bertujuan mengunduh ajaran damai yang ditanam dalam tradisi Jawa terutama yang disemai oleh Sunan Kalijaga. Sunan Kalijaga adalah seorang wali pada abad ke $15 \mathrm{M}$ yang memiliki ajaran bersifat mistis-filosofis. Hingga saat ini, pengaruh Sunan Kalijaga sangat terasa dalam tradisi Jawa sehingga nilai-nilai damai yang ada dalam ajarannya masih dapat ditelusuri dan dikembangkan. Dengan menerapkan studi pustaka, data-data dalam riset ini dikumpulkan dari sumber-sumber yang mengkaji Sunan Kalijaga, peran, pengaruh, dan warisanwarisannya. Oleh karena corak pemikiran keagamaan Sunan Kalijaga bersifat mistis-filosofis, maka aspek mistisisme dan pendekatan filsafat juga digunakan dalam tulisan ini. Paper ini memaparkan temuan bahwa dalam pratiknya, Sunan Kalijaga melakukan permainan bahasa yang dengan cara tersebut ia berhasil memadukan antara nilai-nila i keislaman dengan unsur buda y a dominan yang telah ada sebelumnya yaitu Hindu dan Buddha. Oleh karena itu, alihalih menggunakan istilah Arab, Sunan Kalijaga justru banyak menggunakan istilah Jawa Kuna dan Sansekerta yang lazim digunakan dalam masyarakat Jawa abad 15-16. Hasil dari upaya tersebut, Sunan Kalijaga menghadirkan istilahistilah yang tampaknya kurang Islami namun sarat muatan nilai-nilai Islam. Ijtihad Sunan Kalijaga tidak hanya terwariskan menjadi istilah-istilah, namun juga menjadi praktik, simbol bahkan melembaga. Dari beberapa bentuk tradisi jawa yang diwariskan Sunan Kalijaga dapat diambil bebera pa nilai penting yang mendukung iklim damai. Paper ini memetik nilai-nilai damai ajaran sang Sunan tersebut dengan harapan dapat membendung arus ideologi ekstrim yang akhir-akhir ini semakin membanjiri ruang publik.

Keywords: Sunan Kalijaga; Peace; Mysticism; Javanese

\section{Introduction}

Today is 'The Age of Terror'. The term was officially used by Donald Trump, the US President in his speech. ${ }^{1}$ It depicts the era where peace is ripped by act of terror and extreme ideologies. Nowadays, terrorism

1 Understanding The Threat: Radical Islam And The Age Of Terror, https://assets. donaldjtrump.com/Radical_Islam_Speech.pdf. 
has continued to be a core issue following the organized 9/11 attack that gravely affected the United States in 2001. Terrorism began to rapidly and massively spread out abroad, including to Indonesia.

The global spread of terror causes the demand for peace ideology to be created. People recount their culture and religious traditions to build peace and inhibit extreme ideology of terrorism from spreading. The demand for appraising local tradition also appeared in Java, the most prominent and habituated island in Indonesia. The Javanese tradition is an early legacy of the Indonesian Islam or Islam Nusantara around the $15^{\text {th }}$ century. It is the period of accommodation when Islam encountered previous great traditions in the archipelago (e.g., Hinduism, Buddhism). Therefore, the main character is a peaceful accommodative Islam.

Before Islamic culture dominated the country, Indonesian archipelago was largely influenced by Indian culture, particularly through Hinduism and Buddhism religious tradition. Java, as well as Sumatera, was the center for Hinduism tradition for centuries. ${ }^{2}$ The transition period from Hinduism and Buddhism to Islam is a significant part of history by which the new shape of Javanese was formulated. During that period, the most notable figure was Sunan Kalijaga.

Sunan Kalijaga was born as Raden Mas Syahid or Raden Said at 1450 AD in Tuban, East Java. He is known as Prince of Tuban, Raden Abdurrahman, and Lokajaya. He lived during the end of Majapahit period, the greatest Hindu Kingdom in the archipelago. It was during the transition period from Hindu to Islam when the Demak Islamic Kingdom grew significantly following several conquests. Sunan Kalijaga lived for approximately a hundred years and experienced the rise of several Islamic kingdoms (e.g., Demak, Cirebon, Banten, Pajang, \& Mataram Islam).

\footnotetext{
${ }^{2}$ Dheen Mohamed, "Towards an Islamic Theology of Hindu-Muslim Relations", The Muslim World, vol. 107, no. 2 (2017), 156.
} 
Sunan Kalijaga was a great figure in the Javanese literature and folklore. Javanese people considered him as a prominent saint who practiced mysticism during his life, alongside Syekh Siti Jenar, another well-known figure who adopted the Al-Hallaj path of Sufism. Sunan Kalijaga is better known as a historical figure in Javanese, compared to other opinions who claimed him and Walisanga (the nine saints) as mere folklores. Sunan Kalijaga and Syeikh Siti Jenar were known as wali (saints) who tried to find the balance between Islamic faith and local culture that was influenced heavily by Hinduism and Buddhism at that time. Both managed to build a bridge between Javanese tradition and Islamic teaching. However, after Syeikh Siti Jenar was sentenced to death by the saints forum, Sunan Kalijaga became the only guardian who maintained the adjustment between Islam and prominent Javanese culture.

Sunan Kalijaga mysticism is relatively different from Syeikh Siti Jenar. According to Achmad Chodjim, Syeikh Siti Jenar focused more on achieving "Diri Sejati" [The True Self] while Sunan Kalijaga was more concerned in guiding people's daily activity to help them understand "Sangkan Paran" [The Source and The Objective] $]^{3}$. Nevertheless, both taught the doctrine of "manunggaling kawula gusti" [human and God communion]. The True Self can only be achieved when someone has experienced unity with God. However, Sunan Kalijaga took a simpler approach. He taught people about where they came from and where they will go after death. The source and the objective are the same; He called It "Sangkan Paran".

This paper will not discuss Syeikh Siti Jenar, nor compare these two saints, but focuses on Sunan Kalijaga. This is done because of several reasons; First, Sunan Kalijaga's mystic path was more practical and applicative compared to Syeikh Siti Jenar even though Sunan Kalijaga also

\footnotetext{
${ }^{3}$ Achmad Chodjim, Mistik dan Makrifat Sunan Kalijaga, Jakarta: Serambi, 2003, 14.
} 
practiced semedi [meditation]. In other words, Sunan Kalijaga withdrew himself less than Syeikh Siti Jenar. Second, Sunan Kalijaga created many traditions that became icons of current Javanese culture such as wayang, tembang or gendhing, sekaten, gerebeg, selametan, and so on. Therefore, the influence of Sunan Kalijaga is felt more by the society today compared to those from other wali.

Although Sunan Kalijaga was well known as a Muslim saint, he did not only spread Islamic teaching. Instead, he also adopted several Hindu and Buddhism elements that previously influenced Javanese identity for hundred of years. Therefore, it is understandable when Sunan Kalijaga defined his mission by saying "Jawa digawa, Arab digarap" meaning that both Javanese and Arabic culture will be developed together. A question rests in how Sunan Kalijaga combined Arab influences and previous Javanese culture. Hypothetically, this study is confident to put mysticism as the core issue.

As the core issue, Sunan Kaijaga mysticism will be analyzed through a philosophical approach. The paper focuses on how Sunan Kalijaga employs language as a tool to spread Islamic teachings, particularly in his path of mysticism. We borrowed the theory of language by Wittgenstein that is considered as a significant framework for discussing language philosophically by scholars.

Previous studies on this issue are extremely rare, but not impossible to find. For example, Akhtar is one such scholar who explored mystic interpretation of sufi (and Muslim saint). He explored several factors that made Sufi tafsir "mystical" at the level of hermeneutics. His case study on Sahl al-Tustari's (d. 283/896) tafsir identified the intersection of three key founding elements for an influential hermeneutical method of mystical experience in early Islam: (1) the use of an esoteric scriptural hermeneutic based on an exterior-interior (zähir-bitin) interpretive framework; (2) the 
use of supererogatory invocation (dhikr) of the Names of God (al-Asma al-Husnāa); and (3) the achievement of a state of "certainty" (yaqin) that facilitates the acquisition of mystical perception (basar) of God's Oneness and the reception of knowledge ( $m a^{\prime}$ rifa) and wisdom (hikma) from the unseen (al-ghayb). ${ }^{4}$

The role of Muslim saints in introducing Islamic tenets to pre-Islamic society was also much discussed by Susanto. Susanto discussed the saint spiritual leadership, with characteristics based on the divine aspect, done with honesty and sincerity, drawing public sympathy and mobilizing them to follow the saint teachings. Susanto found that the success of the nine saints, including Sunan Kalijaga, in educating Javanese people is because of their concern on the efforts to meet the basic needs of the society and provide models to follow. ${ }^{5}$ This paper also discusses how the products of language-games turned into Javanese culture. Previous studies that explored the relation of language-games and culture is Tleubayev et al. ${ }^{6}$ The position of this paper is quite different because Wittgenstein philosophical analyzes is conducted to observe the most influential Javanese mystic and sufi, Sunan Kalijaga. The study was significant in mainstreaming culture of peace and harmony, particularly for Javanese and Indonesian context that nowadays suffered from the spread of violent and extreme interpretation of Islam.

\section{The mystic philosophy}

It is important to build a solid understanding of mysticism before trying

${ }^{4}$ Ali Humayun Akhtar, "Identifying Mysticism in Early Esoteric Scriptural Hermeneutics: Sahl al-Tustari's (d. 283/896) Tafsir Reconsidered”, Journal of Islamic and Muslim Studies, vol. 2, no. 2 (2017), 38-52.

${ }^{5}$ Nanang Hasan Susanto, "Walisongo's Educational Leadership through Modelling and Fulfilment of Human Basic Needs", Jurnal Pendidikan Islam, vol. 6, no. 2 (2017), 311.

${ }^{6}$ Seraly Sh Tleubayev et al., "The Game as the Essence of Culture", Espacios, vol. 38, no. 54 (2017), 29-41. 
to understand the roles of Sunan Kalijaga. Rigorously, mysticism differs from magic. Thus, a clear distinction between mysticism and magic needs to be made. The desire for mysticism is one for love. It is a unification of will and emotions, namely love, with the Ultimate Object of love (God). Meanwhile, magic has the desire for knowledge. Thus, will is united with intellect in an impassioned desire for supersensible knowledge. In other words, mysticism wants to give while magic wants to receive. Magic wants to achieve knowledge or power by doing certain practices, but mystic dedicates themselves in giving love, because they believe that providing love is the way to get closer to God. It must have nothing but love, the unconditional love. To mystic, love is their way and luggage in their journey.

According to Underhill, there are at least five characteristic of mysticism $^{7}$ : 1) Active and Practical: Mysticism is beyond just believing, it requires action. Mystics have acknowledged that people tend to struggle believing in their experience unless they experienced it themselves. People will only enjoy mysticism if they experience it through practice. Thus, mysticism is more practical than it is theoretical. 2) Transcendental and Spiritual: The practice of mysticism does not necessarily show similarities to magic or religious ritual even though it must be practiced. Instead, it is an entirely spiritual activity. It not only includes giving worship, sacrificing animal, or periodically praying as seen in magic and religion. It is not a ceremonial activity, but it is extremely spiritual, moves straight up directly. It is a transcendental relationship with God, and often done without any medium. 3) The mystic is a lover: To be a mystic, someone needs to speak the language of love. It requires total dedication of the desire to be in love with the Absolute. In fact, some mystics perceived

\footnotetext{
${ }^{7}$ Evelyn Underhill, Mysticism, A Study in the Nature and Development of Man's Spiritual Conciousness, New York: A Meridian Book, 1911, 78-92.
} 
the Absolute as a living person to be loved, because to be mystic does not mean we need to lose our personality. Therefore, mystic only have one business, love. They also only have one method, give love. Giving love to God does not mean they will refuse to give love to others. This is because a piece of God is embedded in everyone, if only by the spark. 4) Mysticism entails definite psychological experience: Mystic realized that there is something Absolute and Perfect, influencing them to have the will to be like that as well. They adapt themselves with the Absolute through transmutation in order to become united with God. The union with God is the object mysticism. Transmutation is used to rebuild a higher level of self. Mystical experience that began from consciousness is planted in someone to be inward alchemy. By which the permanent consciousness on Absolute will be there. 5) Mysticism is self surrender, pure love, and never self-seeking. Mystics only want "union with the Absolute". They do not want any joy, pleasure, or satisfaction usually described as heaven in many religions. In fact, Rabiah al-Adwiyah said that if she wouldn't mind being thrown to hell as long as it is the expression of God's love for her.

For those who practice mysticism, the possible achievement is a set of state that differs from those that ordinary people have. William James outlined four marks of the mystic state ${ }^{8}: 1$ ) Ineffability (unexpressed); People who experience mysticism cannot express their experience through words. It is not enough to be spoken and written. The words are never appropriate to describe the mystical experience. Therefore, mysticism should be experienced, not studied. 2) Noetic Quality: Mystical experience is more than a mystical state but also a state of knowledge in which mystic will update their understanding of the Truth. Mystic will feel enlightened, granted a revelation, significant, and important.

${ }^{8}$ William James, The Varieties of Religious Experience, A Study in Human Nature, New York: The Modern Library, 1936, 252-253. 
3) Transiency: Mystical state cannot be sustained for long, but the quality can be reproduced in our mind despite being imperfect. Nonetheless, if this experience is repeated many times, it will continue to develop inner richness. 4) Passivity: Mystical state could be facilitated by preliminary voluntary activities such as fixing attention and doing certain bodily performance. They reported feeling like they were grasped by a superior power whenever such consciousness was felt.

In conclusion, although mysticism is a somewhat intangible experience, the practice is done consciously. In other words, mystic experience can generally be understood. The issue is on how to derive the experience into a language that could allow people to understand and imitate the experience.

Philosophically, language is a medium between analytic and expression. It explains the emergence of Language Analytical Philosophy as a branch of the discipline. It sees that philosophical problem will be resolved when grammatical analyses are conducted. In other words, the task of philosophy is to conduct conceptual analysis. ${ }^{9}$

According to Wittgenstein, Analytical Philosophy frees epistemology from unclear terms, also known as language criticism. He argued that everything experienced should be able to be expressed. Language acts as both the medium and limit for thought expression. By this understanding, he constructed the picture theory. The theory stated that there is an ultimate relation between language and factual reality, or corresponded between proposition and state of affairs. Therefore, a proposition should always reflect the reality.

The Wittgenstein approach, however, became problematic when encountering noetic experience in mysticism. Noetic means non-empirical

\footnotetext{
${ }^{9}$ Kaelan, Filsafat Bahasa: Masalah dan Perkembangannya, Paradigma: Yogyakarta, 2002, 80 .
} 
experience, a tent to intuitive experience. Therefore, metaphysics, including mysticism, is beyond the limit of language. Mystical experience is unutterable, ineffable, and unexpressed because it will turn into nonsense when we impose to express it.

To solve the problem, Wittgenstein rectified his previous assumption on language function through a Philosophical Investigation. Instead of defending the single function of language, he claimed that language has various functions. To understand the claim, attention should shift to the logic of everyday language (common sense) than the perfection of language composition. Therefore, logic is only one part of the language function, there is also performativity utterance. The performativity, therefore, is difference with the descriptive and factual based utterance as Wittgenstein believed earlier. This understanding by Wittgenstein is famously known as the language-games. With respect to Wittgenstein, Kaelan explained the language-games by saying: the meaning of a word depends on the use in a sentence, the meaning of a sentence depends on its use in language, and the meaning of language depends on its use in life" ${ }^{10}$ According to Wittgenstein, language was not only one of the central problems of philosophy; but also the key to their solution. ${ }^{11}$

\section{Sunan Kalijaga philosophical mysticism}

It is interesting to investigate the ways Sunan Kalijaga expressed his Islamic mystical experience in the Javanese cultural context despite existence of previous cultures (e.g., Hinduism). This is particularly relevant in understanding the Wittgenstein philosophical approach on language function. Sunan Kalijaga was excellent at formulating his experience.

\footnotetext{
${ }^{10}$ Kaelan, Filsafat Bahasa: Masalah dan Perkembangannya, Paradigma: Yogyakarta, 2002, 80 .

${ }^{11}$ John Gibson and Wolfgang Huemer, The Literary Wittgenstein, London and New York: Routledge, 2004, 1.
} 
Wittgenstein once indicated that theology is construed as an expression of religious grammar. ${ }^{12}$ Sunan Kalijaga contributed to such concept by using several religious terms in the Javanese context. As many other Sufi tradition, the terms are inherited to the next generation by ij】zat al-sam凹(a certification of audition), ${ }^{13}$ the next scholars will then write those words into several classical books. The terms invented by Sunan had a strong significance in the Javanese Islam theology, which is very mystical. The following are the terms formulated by Sunan Kalijaga to express his mystical experiences.

\section{Tarak Brata for meditation}

Sunan Kalijaga prefered to use tarak brata, compared to Arabic terms such as tahanuts, khalwah, tafakur and i'tikaf, in referring to the meditative practice in Islam. As conducted by many mystics, Sunan Kalijaga also practiced meditation. His tarak brata was really famous because it gave him his name. At that time, he meditated after an impressive meeting with Sunan Bonang, an older wali who became his religious teacher. He meditated at a river bank for a whole year until his body was full of moss. This famous meditation at the river bank resulted in him being known as Kalijaga [river guardian]. Before this meditation, Sunan Kalijaga also meditated under the gurda tree and inside of Sorowiti Cave, Jungle of Panceng, Tuban East Java ${ }^{14}$.

According to Chodjim, Sunan Kalijaga practiced meditation by controlling his breath. There are four kinds of breathing exercise in Islam

\footnotetext{
${ }^{12}$ Robert L. Arrington, “Theology as Grammar: Wittgenstein and Some Critics”, Robert L.Arrington and Mark Addis (eds.), Wittgenstein and Philosophy of Religion, London and New York: Routledge, 2001, 168.

13 Sara Nimis, "Sainthood and the Law: The Influence of Mysticism in Eighteenth Century Pedagogy of the Fuqahă’”, Journal of Arabic and Islamic Studies, vol. 14 (2014), 182.

${ }^{14}$ Pvurwadi, Sufisme Sunan Kalijaga; Menguak Tabir Ilmu Sejati di Tanah Jawa, Yogyakarta: Sadasiva, 2005, 13.
} 
Jawa tradition believed to be the meditation style of Sunan Kalijaga, namely napas, tanapas, anpas, and nupus. Napas is placed at suweda, it is "the binder of body", the appearance is merely air that blows from our body. Tanapas is placed at puser (navel), anpas is positioned at and around the heart, while nupus is placed at the very core of the heart where it is rich with oxygen. Those breathing exercises are practiced to produce inner composure. ${ }^{15}$ The practice is very much influenced by HinduBuddha meditation.

The practice of ascetics is also known in Islam. The Prophet Muhammad often kept aloof (khalwah) to reflect (tafakur) in the Hira cave for a certain period. The first revelation of Gabriel was a product of a long retreat. Thus, without intending to ignore the will of God in choosing him, the true enlightenment came from an ascetic process. Additionally, ascetic practices to date can be seen from the advice of doing i'tikaf, escaping a busy world, and performing dhikr at the mosque.

However, Sunan Kalijaga did not use the term tafakur, khalwah, i'tikaf, and the like from Arabic. He used the term tarak brata that is closer to the Hindu-Buddhist culture. This is the language-games by Sunan Kalijaga that ensured Islamic practice to receive public justification despite minimal understanding of Arabic terms. Sunan Kalijaga spoke in the context of the community.

\section{Sarira Tunggal for the peak of mystical experience}

The terms wahdatul wujud, hulul, and ma'rifat are often used to describe the apex of the mystical path in Islamic mysticism, however Sunan Kalijaga prefered to use the term sarira tunggal. It marked the difference from Sukma Jati of Sheikh Siti Jenar. Sunan Kalijaga meditated to feel unity with God. He said "lamun nedya muja samadi...dumadi sariro

\footnotetext{
${ }^{15}$ Achmad Chodjim, Mistik dan Makrifat Sunan Kalijaga, Jakarta: Serambi, 2003, 55.
} 
tunggal, tunggal jati swara awor ing hartati" plainly translated as "but if you do meditation... become united, one truth, like voices combined" 16 Through samadi someone can achieve steadiness in which Sang Permana (consciousness) can meet Sukma Jati (the True Self).

Sunan Kalijaga never explain what God looks like, just that it is "tan kena kinaya ngapa" (un-describe-able). He also said "Pangeran pan ora rupa / nora arah nora warni / tan ana ing wujudira / tanpa mangsa tanpa enggon" [God has no appearance, no direction nor color, has no material, and beyond the time and space].

\section{Mati Sajroning Urip for simple life allurement}

Sunan Kalijaga has many names, one of which is Syeikh Malaya meaning self-dies ${ }^{17}$. He was given this name because he has punished worldly desire and showed total surrender and love towards God. He is considered as someone who has died because he has no worldly desire despite being alive. Thus, he is described as mati sajroning urip [died before living]. ${ }^{18}$ However, it differs from annihilation that is usually practiced by many Sufi. Annihilation seeks to unite with God (fana fillah) and the messenger (fana fi-al-rasul). Meanwhile, Sunan Kalijaga used mati sajroning urip to practice zuhd, a minimalist daily life style or anti-glamour.

\section{Sangkan Paraning Dumadi for destination of human being}

Sangkan means the source. It is a condition before humans come to the worldly life. Paran means destination to which human will go back after

\footnotetext{
${ }^{16}$ Achmad Chodjim, Mistik dan Makrifat..., 172.

${ }^{17}$ After learned from Sunan Bonang, Sunan Kalijaga also learn from Sunan Ampel and Giri. After that, he moved to Pasai and East Patani (Thailand). In Patani he cured the King who got skin disease. He became a famous religious teacher as well as healer in Patani. He usually called Raden Sa'id (his childhood name) and Syeikh Malaya, his honorable name there.

${ }^{18}$ Achmad Chodjim, Mistik dan Makrifat..., 10.
} 
IJIMS: Indonesian Journal of Islam and Muslim Societies, Volume 8, Number 2, December 2018: 281-308

they died. Dumadi literally means being created. It refers to all creatures in the universe. People were asked to believe that they came from a single source and will go back to the same place.

Sangkan Paraning Dumadi itself was described as Kajeng Sejati [the Main Tree] or Syajarat al-Yaqin. It is frequently called "kusuma anjrah ing tawang" [flower grows in the sky but intrinsically implies pre-worldly life]. After that there are Nur Muhammad, then Sang Urip or Roh Ilahi.

\section{Salat Daim for having religious spirit in a whole lifetime}

Sunan Kalijaga criticized people who performed shalat without knowing exactly what they did. Sunan Kalijaga called them "kadi kanulup kaga/ punglune den sawur/manuke mangsa kenaa" [like a man who shoots a bird, the bullet has been shot out but no bird falls down]. A person does something but receive nothing. It is almost similar with Eckhart's understanding that there are people who found the way but did not find $\operatorname{God}^{19}$. To find God, people need a more direct way without being trapped in anything, including certain religious ritual.

In contrary, Sunan Kalijaga proposed what he called as salat daim, the uncut praying wherever, whenever, and in whatever condition. Sunan Kalijaga said in Suluk (book of songs) Linglung "Salat daim tan kalawan, met toya wulu kadasi, salat batin sabenernyo, mangan turu sahwat ngising." [Salat daim means that nothing can be an obstacle, it does not need wudhu, it is the real salat, can be done while you eat, sleep, make love, and even while loosening the bowels]. He also said in Suluk Wijil (Wijil book of songs): "pangabektine ingkang utami / nora lan wektu / sesolahira punika mangka sembahe / meneng muni puniku / sasolahe raganireki / tan simpang dadi sembah / iku ingaran niyat kang sejati / puji tan papegatan”20

\footnotetext{
${ }^{19}$ Syafaatun Almirzanah, When Mystic Masters Meet: Paradigma Baru Dalam Relasi Umat Kristiani-Muslim, Jakarta: Gramedia, 2009, 199.

${ }^{20}$ Suluk Wujil, article 39, as quoted by Achmad Chodjim, Mistik dan Makrifat Sunan
} 
[the great devotion is at whenever, all you do is your praying, your silent, your talk, whatever your body do should be a prayer as well, that is the truest keenness, the uncut prayer].

Therefore, religious ritual is not the most important aspect for Sunan Kalijaga. Instead, the core value is on knowing and always remembering God. Whatever people do can be a prayer as long as they do it in the name of loving God.

\section{Possessed by Prophet Khidir for enlightenment process}

Sunan Kalijaga met an old man named Khidir who walked on water. Many questions and answers arose during that meeting. Khidir asked Sunan Kalijaga to enter his body through his ear. After Sunan Kalijaga stayed in Khidir's body, he finally received a steady heart after seeing an ocean and light.

It seems like a mystical experience rather than a historical event. It is a process by which Sunan Kalijaga got enlightenment, allowing him to answer many puzzles of his life. His eyes and heart were opened because of enlightenment. His meeting with Khidir was an imaginary dialogue based on self-discussion.

According to Purwadi, Khidir taught Sunan Kalijaga three stages of the mystical experience; tarikat, hakikat, and makrifat. ${ }^{21}$ We believe that ngelmu (knowledge) is the result of his deep contemplation. He faced his world, received many lessons from other wali, and combined Islam with cultural context. Therefore, he needs more contemplation. His contemplation resulted in many brilliant ideas.

Kalijaga, Jakarta: Serambi, 2003, 129.

${ }^{21}$ Purwadi, Sufisme Sunan Kalijaga: Menguak Tabir Ilmu Sejati di Tanah Jawa, Yogyakarta: Sadasiva, 2005, 23-31. 


\section{Perpetuate Sunan Kalijaga philosophy in contemporary Javanese tradition}

Sunan Kalijaga gained enlightenment through phases of learning and meditation; however, he manifested the result through a much practical way in his social life. The practices resulted in the continuous development of the Javanese tradition. Therefore, the practice of the saint became a very important legacy for current Javanese tradition. Mysticism runs deep in the tradition for hundreds of years. Despite the decrease cause by modernity, mystical teachings continue to persist. The tradition is acknowledged as a genius achievement in the Javanese history of civilization.

Through several traditions, Sunan Kalijaga's philosophy on mystical experience, including his language-games, are continued. Below are traditions that conserve Sunan Kalijaga's inventions:

\section{Wayang}

Sunan Kalijaga employed wayang to be the media in teaching people to know God and guide morality. According to Ponder, Wayang owed something to Hindu influence for some of the best known stories. The stories are taken from writings of the Hindu period in Java. However, figures of the various characters in the stories, grotesque and hideous though some of them are, have a mild, benevolent, and very far removed from the horrible and often obscene hideousness of so many Hindu idols and images in India. ${ }^{22}$ Originally, wayang before the era of Sunan Kalijaga is shown as a scroll with pictures. It was called wayang beber. This kind of wayang was also popular in other countries, such as China, Japan and India. However, some wali (saint), especially Sunan Kalijaga, made

\footnotetext{
${ }^{22}$ H.W. Ponder, Java Pageant, Impresion of the 1930s, New York: Oxford University Press, 1988, 48.
} 
a more attractive and moveable wayang, called ringgit wacucal or wayang kulit.

Each figure in wayang has its own character. They are the image of diversity. Sunan Kalijaga realized that this world is filled with people with diverse characters and attitudes. He used Hindu epics, particularly Mahabharata and Ramayana that are considered well-known at that time. However, he used his creativity to infiltrate Islamic message inside the story including in portraying the figures.

The most famous figure in wayang influenced by Islamic mysticism is Semar. According to Franz Magniz Suseno, Semar is the most loved of all wayang figures. When Semar appears on screen, he encounters a wave of sympathy from the audience. Semar is the most important figure in wayang. He is portrayed as wise, simple, popular, kind, laughable, and a protector. ${ }^{23}$

Semar means samar, the "in between" position, Semar is a moderate and vague figure in Wayang. He looks like both a man and a woman. Semar is a bodily appearance of Sang Hyang Ismaya. Semar is God with badan wadag (human body) and worldly life. Semar also known as Sang Hyang Manikmaya means twin existence both in kahyangan and the world.

According to Soehadha, Semar is the concept of God in Javanese culture. Semar is a portrait of manunggaling kawula gusti in wayang story. Semar lives in both jagad gede lan jagad alit [macro-cosmos and microcosmos]. Through the figure of Semar, Sunan Kalijaga delivered several messages: people should be united with God, life should be balanced and not extreme to one side only, worldly life is just mampir ngombe [temporary, to do good deeds], life should be full of dharmahita [good service and

${ }^{23}$ Franz Magnis Suseno, Javanese Ethic and World View; The Javanese Idea of the Good Life, Jakarta: Gramedia Pustaka Utama, 1997, 185. 
dedication], urip samadaya [life should be simple, not glamorous], alus ing pambudi [behave calmly], and so on. ${ }^{24}$

Therefore, Sunan Kalijaga taught people to be mystic but not merely ascetic through Semar. To be mystics who does not withdraw themselves from daily life but contribute in it with new vision of kindness. There are still various aspects in wayang that combines Islamic and Hindu mysticism.

\section{Tembang}

Sunan Kalijaga was also known as a composer. He created many tembang [songs] that people collected as Suluk [book of songs]. Tembang itself is divided into numerous types of songs, traditionally known as macapat. Historically, macapat already existed before Sunan Kalijaga, but he had a great contribution in developing this art. Many lyrics created by Sunan Kalijaga are well-known today, such as Lir ilir. Some of his songs were also sung in Langgar and Mosque in villages after azan and before iqamah, usually called puji-pujian.

In macapat there are patterns of song, such as Asmaradhana, Dhandanggula, Maskumambang, Kinanthi, Pocung, and so on. People can change the lyric as they want, depending on the message they want to give. The pattern itself implies that certain nuance or tone of the song; can be happy, hopeful, sad, and so forth.

In ancient Javanese society, oral tradition was stronger than written tradition. Many people enjoyed listening to songs and storytelling, but especially the former. Songs are easier to memorize because they have rhythms. By memorizing the song, people also starts to memorize the message. The message has religious and ethical teachings. Sunan Kalijaga

\footnotetext{
${ }^{24}$ Moch. Soehadha, "Ambiguitas Semar, Ambiguitas Manusia Jawa", Esensia; Jurnal Ilmuilmu Ushuluddin, Vol. 4, no.1 (January 2003), 118-122.
} 
used this media to spread out his teaching because the effectiveness.

Sunan Kalijaga's method of using tembang influenced many future Javanese scholars to imitate his style. Yasadipura, Ranggawarsito, Mutamakin, and so on also wrote sastra gendhing [book of song] such as Serat Wirid Hidayat Jati, Serat Centhini, Serat Cebolek. Those serat [Javanese book] are extremely familiar to some mystical term such as wahdat al wujud, ittihad and hulul..$^{25}$

\section{Kraton Tradition: Sekaten and Gerebeg}

In order to make song (as well as wayang) more attractive and appealing, Sunan Kalijaga also created gamelan [Javanese ensemble]. Gamelans that belonged to Sunan Kalijaga were often presented in front of the public during Sekaten and Gerebeg traditional ceremony. The names of Sunan Kalijaga's gamelan are Kiai Guntur Madu presented in Gerebeg Keraton Solo, while Kyai Guntur Sari and Kiai Nogowilogo in Sekaten Keraton Yogyakarta. There are also gamelan Kyai Sekati and Nyai Sekati.

Gerebeg ceremony originally came from the pre-Islam era of Java. Ancient Javanese kings usually conducted a ceremony called wilujengan nagari. ${ }^{26}$ However, Sunan Kalijaga influenced parts of that tradition. The ceremony is no longer merely for the country but also to memorize certain Islamic holy days such us Gerebeg Mulud to remember the birthday of prophet Muhammad and Gerebeg Besar in Muharram month. Mataram Kingdom, under the influence of Islam, kept this tradition even until today.

After Mataram adopted the teachings of Sunan Kalijaga, the view about the relationship between the King and people also changed. Manunggaling

${ }^{25}$ H. Abdul Djamil, "Aspek Islam dalam Sastra Jawa", in Darori Amin (ed.), Islam $\mathcal{E}$ Kebudayaan Jawa, Yogyakarta: Gama Media, 2000, 167.

${ }^{26}$ Irwan Abdullah, Simbol, Makna dan Pandangan Hidup Jawa; Analisis Gunungan pada Upacara Gerebeg, Yogyakarta: Balai Kajian Sejarah dan Nilai Tradisional, 2002, 23. 
kawula gusti has been interpreted as Jumbuhing kawula-gusti [the union of the subject people and the lord]. Therefore, it was not only used in the term man and God relation but also relationship between people and the king. ${ }^{27}$ Kings of Mataram were often described as the owner of everything in the world, not only of the country and property but also one's very life. Kraton was also influenced by the teaching of wayang in which a king was described as gung-binathara, bau dendha nyakrawati [grand celestial being, maintaining the law and ruling the world]. Usually he would also be considered as wise, portrayed in the words ber budi bawa leksana, ambeg adil para marta [pure-hearted and full of justice for all creatures]. ${ }^{28} \mathrm{~A}$ king should be just, fair and humble in using his power because they believe that Melik nggendhong lali [a power can make people default], and that is the opposite of , ambeg adil para marta as taught by Sunan Kalijaga in wayang. ${ }^{29}$ Therefore, it can be said that the mystical view of Sunan Kalijaga was also implemented in Keraton policy.

\section{Slametan}

Slametan is a traditional ritual or ceremony that aims to achieve wellbeing for those who are still alive and those who have passed away. Originally, slametan was animism and Hindu tradition; However, Sunan Kalijaga infiltrated donga [Islamic prayer] in slametan. It resulted in a combination of ancient ceremony with Islamic teachings.

Most Slametans are done to memorize certain event or phase. For example, some slametan are used to ask safety for the deceased; Surtanah or geblak are done in funeral rites, nelung dino (after three days), mitung dino (seven days), matang puluh (forty days), nyatus (a hundred), mendhak

${ }^{27}$ G. Moedjanto, The Concept of Power in Javanese Culture, Yogyakarta, Gadjah Mada University Press, 1993, 107.

${ }^{28}$ G. Moedjanto, The Concept of Power..., 102-103.

${ }^{29}$ Sindhunata, Petruk Jadi Guru, Jakarta: Penerbit Buku Kompas, 2006, 61. 
sepisan (one year), mendhak pindo (second year commemoration), and nyewu (thousand days). ${ }^{30}$ There are also slametan for pregnancy such as Neloni (three month), mitoni (seven month). There are numerous other slametan in the Javanese culture, like bancakan, merti dusun, and so forth.

\section{Kebatinan}

Another influence of Sunan Kalijaga is in Aliran Kebatinan or Kejawen (Islam Jawa). There are many schools of aliran kebatinan in Java such as Sumarah, Sapto Dharmo, Tritunggal and so on. The similarities among kejawen schools are their mentality that accommodates respect to all religious expression to create unity and harmony of live. ${ }^{31}$ For example, in Kebatinan Tritunggal there is a teaching that says Ngagama ojo ngrusuhi agami / ngagama ojo ngrusak kamanungsan / ngagama kudu nawurken wawang ${ }^{32}$ [being religious means to not destroy religion, not hurt humanity, and has to extend to a good representation]. In tritunggal ngagama, agami refers to other religion, particularly the official religions in Indonesia.

The mystical teaching of Sunan Kalijaga that is characterized as being friendly to tradition and diversity are adopted by aliran kebatinan. Tritunggal believed that religion is like a case, while the essence is budi luhur [good deeds]. They also saw religious ritual the way Sunan Kalijaga viewed shalat daim. Similarly, kebatinan also practices meditation through breathing exercise and contemplation before going back to the society as an enlightened person. Ki Martosupadmo, a kebatinan member explained that Kebatinan is the source of Life called Budaya [culture], the Light of

\footnotetext{
${ }^{30}$ Budiono Herusatoto, Simbolisme Dalam Budaya Jawa, Yogyakarta: Hanindita, 2005, 89.

${ }^{31}$ M. Murtadho, Islam Jawa; Keluar dari kemelut Santri dan Abangan, Yogyakarta: Lapera, 2002, 12.

${ }^{32}$ Burhan Ali, "Kebatinan dan Keberagamaan dalam Paguyuban Tritunggal Yogyakarta", Thesis, Yogyakarta: CRCS-UGM, 2006, 139.
} 
God, or God's Luster. Everyone can contact Life, although the path to it is difficult. The way is through semedi; to clear our mind every day and do something good. He also asked to not be steered by emotions, to accept our position in life, and be sincere. Semedi is the exercise to get to know Life. People train it through conscious, rhythmical breathing until the point that consciousness vanishes. Next, they will get into contact with God, Hyang Suksma, who equates with Budaya, which stands from cahya (light, luster) of Hyang Suksma that is Life. ${ }^{33}$

\section{Building peace through mystic philosophy}

The succeed of Sunan Kalijaga in merging previous Javanese tradition with Islamic mysticism heirs the significance for current Javanese life especially in managing diversity of religions and thoughts. Many traditions influenced by Sunan Kalijaga are permeably absorbed in the Javanese cultural attitude and behavior. This Javanese attitude and behavior - formally called "Perilaku Budaya" by Yogyakarta government - is nowadays being re-actualized since it is believed to be a mode of showing friendlier attitude to other ethics including religious-fundamentalist ethic that recently flourishes. ${ }^{34}$ In the other words, Perilaku Budaya has a significant role in today's life, especially in developing tolerance and peace in Yogyakarta and Central Java - where the activities of Sunan Kalijaga frequently took place.

Some traditional practices believed to be a legacy of Sunan Kalijaga's influence, such as slametan, grebeg, and so on, produce offerings that have symbolic meaning. Below are examples of ritual symbols and meanings: $:^{35}$

${ }^{33}$ Niels Mulder, Dosing Java, An Anthropological Detective Story, Yogyakarta: Kanisius, 2006, 41.

${ }^{34}$ R.M. Wijoseno Hario Bimo, Kajian Profil Perilaku Budaya Yogyakarta Dalam Segmen Kajian Terhadap Merti Desa di Daerah Istimewa Yogyakarta bagi Pengembangan Karakter Bangsa. Yogyakarta: Biro Administrasi Kesejahteraan Rakyat dan Kemasyarakatan DIY, 2013, 30.

${ }^{35}$ R.M. Wijoseno Hario Bimo, Kajian Profil Perilaku Budaya..., 53. 
Table 1 Ritual symbols and meaning

\begin{tabular}{cll}
\hline \multicolumn{2}{c}{ Symbol } & \multicolumn{1}{c}{ Meaning } \\
\hline 1 & Tumpeng, Tumpeng lanang & Divine \\
\hline 2 & Pisang Raja Pulut & Strong relation between Ruler and people \\
\hline 3 & Ayam Ingkung & Honesty, veracity \\
\hline 4 & Tumpeng Wadon, jenang abang putih & Respect, devotion, and loyalty \\
\hline 5 & Jenang ireng & Clannish \\
\hline 6 & Kolak, Jenang palang & Rejecting evil \\
\hline 7 & Apem, kupat & Lowly \& confession \\
\hline 8 & Sambel Gepleng, tukon pasar & Celebrate diversity \\
\hline 9 & Jadah, gudangan, kupat lepet & Tolerance and unity \\
\hline 10 & Wajik & Harmony \\
\hline 11 & Dhem-dheman, air kendi & Peace \\
\hline 12 & Brakalan & Down to earth \\
\hline 13 & Kendi ijo, nasi ambeng, srabi kocor & Charity \\
\hline 14 & Srabi & Affection \\
\hline 15 & Gedang Ayu & Graciously \\
\hline 16 & Gudangan, Srabi Kocor & Eco-friendly \\
\hline 17 & Ayam Jago & Responsible \\
\hline 18 & Ndhas Kebo, Wedhus kendit & Voluntarily \\
\hline & & \\
\hline
\end{tabular}

Beside the symbols, perilaku budaya (cultural behavior) also includes daily cultural conduct known as unggah-ungguh. One of the traditionalists and religious scholars who largely implemented the teachings of Sunan Kalijaga was Cak Nun (Emha Ainun Nadjib). He also asserted the significance of unggah-ungguh as a key of peace and harmony in the society. According to Cak Nun, unggah-ungguh as a semantic means respect to others (unggah) according to their position (ungguh). It is practiced by using polite language and conducting good attitude towards others. ${ }^{36}$ Unggahungguh prevents someone from egoistic nature and encourages him or her to be humanistic. It is important to counter the recent ideology of extremism that teaches the contrary. Extremists, by their claim of truth,

\footnotetext{
36 “Unggah-Ungguh", CakNun.com (30 Dec 2017), https://www.caknun.com/2017/ unggah-ungguh/, accessed 17 May 2018.
} 
easily blame others and punish them with terror. Extremist has no respect for humanity.

Building peace among Javanese is mostly conducted by art and cultural approaches. For example, wayang which is also acknowledged as a legacy of Sunan Kalijaga is the most popular art that effectively cultivate peace. The teaching in wayang story often asks people to live peace and harmony, and respect others. Wayang is also used as a conflict resolution approach, namely that truth and good deed will always triumph in the end. It implies the call to do well and never start a conflict with others. Therefore, no doubt, it is a teaching of peace and harmony. Tembang is also an art that cultivates peace. Macapat is very rich with lyrics that mainstreaming ethic and moral values. Below is an example of Dhandanggula lyrics. Dhandangula is macapat tone that created by Sunan Kalijaga.

Aja nyawang mring bedaning kulit/ Aja nyawang bedaning agama/ Iku kanca nira kabeh/Sanadyan drajadipun/ Luwih cendhek lawan si reki/ Becik den kurmatana/ Sesamaning makhluk/ Yen iku wus katindhakna/ Mesti sira tetep bakal den payungi/ Gusti kang Maha Nasa.

"don't look at skin color/ nor the religion/ they are your friend/ even the social caste is lower than you/ just respect them/ they are human being like you/ if you do this/ may you always receive blessing/ from God".

The text clearly explains the teaching of harmony, especially in respecting people from other religion and ethnicity.

Peace and harmony is a product of cultural events. Grebeg, is traditional ritual in which people with various background 'melt' in one spot. Although it is well-known as Muslim festival, people of other religions are welcome. Slametan is also a cultural-religious ceremony that unifies people. Practiced in many places, especially rural villages, people of all religions are invited even if the home-based of the ritual is a Muslim family. Therefore, slametan is also useful in unifying people and leading them into a state of harmony. 
Besides art and cultural events, peace and harmony are also manifested in government policy. In Yogyakarta, the government emphasizes cultural conduct with the concept of Satriya. This concept was inspired by the attitude of nobles, formulated as sawiji, greget, sengguh, ora mingkuh [be united, motivated, confident, and responsible]. Sawiji [be united] means integrating kawula lan gusti, that can be interpreted as integrating lay people and king or integrating man and God. This understanding is derived from Sunan Kalijaga teaching of sarira tunggal (single soul). With this spirit, Javanese are encouraged to integrate people and government to work together. Sawiji is also interpreted as a call to unite citizens from various religious and ethnic backgrounds. That is an example of how the government tries to implement cultural value into policy. Satriya becomes cultural logo of the Yogyakarta Government which is stipulated by Governor Regulation No. 72 of 2008 concerning Government Culture in the Special Region of Yogyakarta. It is a form of commitment of the Provincial Government in achieving bureaucratic transformation based on the value of Javanese local wisdom. Satriya stands for Selaras (harmony), Akal budi Luhur-jati diri (right character), Teladan-keteladanan (be a role model), Rela Melayani (serve ungrudgingly), Inovatif (innovative), Yakin dan percaya diri (confident), and Ahli-profesional (professional).

Sunan Kalijaga's language-games have turned into teachings of peace and harmony in scripts and tradition. People who firmly conserved the teachings today are called traditionalist rather than scripturalist. Scripturalism Sufism as mentioned by Reese, ${ }^{37}$ does not exist much in the teachings of Sunan Kalijaga. The traditionalists are usually peace lovers. They conserve unggah-ungguh (ethic/norms) that reflects respect and politeness.

${ }^{37}$ Scott S. Reese, "Scripturalism, Sufism and the Limits of Defining Public Religiosity", in Imperial Muslims: Islam, Community and Authority in the Indian Ocean, 18391937 (Edinburgh University Press, 2018), http://www.jstor.org/stable/10.3366/j.ctt1tqxt7c.13. 
IJIMS: Indonesian Journal of Islam and Muslim Societies, Volume 8, Number 2, December 2018: 281-308

\section{Conclusion}

Through brilliant philosophical efforts, particularly by implementing language-games, Sunan Kalijaga was able to translate his experience of Islamic Mysticism into Javanese concepts, terms, and practices. He had similar mystical experience with other Muslim Sufi in the world, but he did not withdraw himself from social life. Sunan Kalijaga conducted meditation to receive enlightenment, but he also dedicated some time for the society afterward. He taught people to be familiar with the source and purpose of live, to love it, and to love each other. He employed both Islamic tradition and previous Javanese culture to win the hearts of the people. His mystical teaching became a great tradition in the Javanese civilization. Some of these traditions still persist today and made up the identity of Javanese culture. Meanwhile, his teaching manifests to cultural attitude and behavior. The spirit of tolerance, peace and harmony, spread through the tremendous values in cultural-religious literature, daily cultural conduct (perilaku budaya) including social norms (unggahungguh), and cultural-art such as wayang [puppet shadow performance] and tembang macapat [traditional song]. It is also generated through cultural ceremony such as grebeg and slametan, portrayed in several traditional and ritual symbols, and developed formally by government through implementing discipline of Satriya. Therefore, although mystical teaching of Sunan Kalijaga has a long history, it is still significant today, especially in countering extreme ideologies like terrorism.

\section{Bibliography}

Abdullah, Irwan. Simbol, Makna dan Pandangan Hidup Jawa: Analisis Gunungan pada Upacara Gerebeg. Yogyakarta: Balai Kajian Sejarah dan Nilai Tradisional, 2002.

Akhtar, Ali Humayun, "Identifying Mysticism in Early Esoteric Scriptural Hermeneutics: Sahl al-Tustari's (d. 283/896) Tafsir Reconsidered”, 
Journal of Islamic and Muslim Studies, vol. 2, no. 2 (2017): 38-52. Ali, Burhan, "Kebatinan dan Keberagamaan dalam Paguyuban Tritunggal

Yogyakarta”, Thesis, Yogyakarta: CRCS-UGM, 2006.

Almirzanah, Syafaatun. When Mystic Masters Meet: Paradigma Baru Dalam

Relasi Umat Kristiani-Muslim. Jakarta: Gramedia, 2009.

Arrington, Robert L. "Theology as Grammar: Wittgenstein and Some Critics", Robert L.Arrington and Mark Addis (eds.), Wittgenstein and Philosophy of Religion, London and New York: Routledge, 2001.

Bimo, R.M. Wijoseno Hario. Kajian Profil Perilaku Budaya Yogyakarta

Dalam Segmen Kajian Terhadap Merti Desa di Daerah Istimewa Yogyakarta bagi Pengembangan Karakter Bangsa. Yogyakarta: Biro Administrasi Kesejahteraan Rakyat dan Kemasyarakatan DIY, 2013. Chodjim, Achmad. Mistik dan Makrifat Sunan Kalijaga. Jakarta: Serambi, 2003.

Djamil, H. Abdul, "Aspek Islam dalam Sastra Jawa”, in Darori Amin (ed.). Islam Eु Kebudayaan Jawa. Yogyakarta: Gama Media, 2000.

Gibson, John and Huemer, Wolfgang. The Literary Wittgenstein. London and New York: Routledge, 2004.

Herusatoto, Budiono. Simbolisme dalam Budaya Jawa. Yogyakarta: Hanindita, 2005.

James, William. The Varieties of Religious Experience, A Study in Human Nature. New York: The Modern Library, 1936.

Kaelan. Filsafat Bahasa: Masalah dan Perkembangannya. Yogyakarta: Paradigma, 2002.

Moedjanto G. The Concept of Power in Javanese Culture. Yogyakarta, Gadjah Mada University Press, 1993.

Mohamed, Dheen, "Towards an Islamic Theology of Hindu-Muslim Relations”, The Muslim World, vol. 107, no. 2 (2017): 156-169.

Mulder, Niels. Dosing Java, An Anthropological Detective Story. Yogyakarta: Kanisius, 2006.

Murtadho, M. Islam Jawa: Keluar dari kemelut Santri dan Abangan. Yogyakarta: Lapera, 2002.

Nimis, Sara, "Sainthood and the Law: The Influence of Mysticism in Eighteenth Century Pedagogy of the Fuqaha", Journal of Arabic and Islamic Studies, vol. 14 (2014): 179-211. 
IJIMS: Indonesian Journal of Islam and Muslim Societies, Volume 8, Number 2, December 2018: 281-308

Ogunnaike, Oludamini, "Annihilation in the Messenger Revisited: Clarifications on a Contemporary Sufi Practice and its Precedents", Journal of Islamic and Muslim Studies, vol. 1, no. 2 (2016): 13-34

Ponder, H.W. Java Pageant, Impresion of the 1930s. New York: Oxford University Press, 1988.

Purwadi. Sufisme Sunan Kalijaga: Menguak Tabir Ilmu Sejati di Tanah Jawa. Yogyakarta: Sadasiva, 2005.

Reese, Scott S., "Scripturalism, Sufism and the Limits of Defining Public Religiosity", in Imperial Muslims: Islam, Community and Authority in the Indian Ocean, 18391937, Edinburgh University Press, 2018, http://www.jstor.org/stable/10.3366/j.ctt1tqxt7c.13.

Sindhunata. Petruk Jadi Guru. Jakarta: Penerbit Buku Kompas, 2006.

Soehadha, Moch., "Ambiguitas Semar, Ambiguitas Manusia Jawa", Esensia; Jurnal Ilmu-ilmu Ushuluddin, vol. 4, no.1 (January 2003): 118122.

Susanto, Nanang Hasan, “Walisongo's Educational Leadership through Modelling and Fulfilment of Human Basic Needs", Jurnal Pendidikan Islam, vol. 6, no. 2 (2017): 311-330.

Suseno, Franz Magnis. Javanese Ethic and World View; The Javanese Idea of the Good Life. Jakarta: Gramedia Pustaka Utama, 1997.

Tleubayev, Seraly Sh et al., "The Game as the Essence of Culture", Espacios, vol. 38, no. 54 (2017): 29.

Underhill, Evelyn. Mysticism, A Study in the Nature and Development of Man's Spiritual Conciousness. New York: A Meridian Book, 1911.

Understanding The Threat: Radical Islam And The Age Of Terror, https:// assets.donaldjtrump.com/Radical_Islam_Speech.pdf.

“Unggah-Ungguh”, CakNun.com (30 Dec 2017), https://www.caknun. com/2017/unggah-ungguh/, accessed 17 May 2018. 